\title{
KORELASI ANTARA MOTOR ABILITY DENGAN KETERAMPILAN DASAR BERMAIN BOLA VOLI PADA SISWA BERUSIA 18-19
}

(Studi deskriptif pada siswa ekstrakurikuler bola voli di SMKN 1 Pacet)

\author{
Ahmad Suherly Dina Saputra1, Budiarto2, Muda Bhakti Hartanto3 \\ Pendidikan Jasmani Kesehatan dan Rekreasi \\ Universitas Suryakancana, Fakultas Keguruan dan Ilmu Pendidikan \\ ahmadsuhrly@gmail.com
}

\begin{tabular}{l}
\hline Info Artikel \\
\hline Sejarah Artikel: \\
Diterima Maret 2019 \\
Disetujui April 2019 \\
Dipublikasikan Juni 2019
\end{tabular}

Keyword:

Motor Ability,

Keterampilan

Dasar Bermain Bola Voli

\begin{abstract}
Abstrak
Motor ability merupakan kemampuan gerak seseorang untuk melakukan aktivitas fisik atau gerak yang diperlukan dalam kegiatan olahraga khususnya bola voli. Penelitian ini bertujuan untuk mengetahui hubungan motor ability dengan keterampilan dasar bermain bola voli. Metode penelitian yang digunakan adalah korelasional. Populasi dalam penelitian ini adalah semua peserta didik yang mengikuti kegiatan ekstrakurikkuler bola voli yang berjumlah 30 orang di SMAN 1 Pacet. Teknik sampling yang digunakan adalah total sampling. Instrumen pertama yang digunakan dalam penelitian adalah barrow motor ability dan instrumen yang kedua yaitu keterampilan bermain bola voli. Analisis data menggunakan SPSS versi 20. Hasil penelitian menunjukan bahwa terdapat hubungan antara motor ability dengan keterampilan teknik dasar bola voli pada siswa. Kesimpulan dari penelitian ini menunjukan bahwa agar dapat menguasai keterampilan dasar bermain bola voli dengan optimal sangat membutuhkan korelasi dari motor ability
\end{abstract}

\section{Abstrack}

Motor ability is the ability to move a person to do physical activities or movements needed in sports activities, especially volleyball. This study aims to determine the relationship between motor ability and basic skill in playing volleyball. The research method used is correlational. The population in this study were all students who took part in volleyball extracurricular activities totaling 30 people at SMAN 1 Pacet. The sampling technique used is total sampling. The first instrument used in the study was the barrow motor ability and the second instrument was the skill of playing volleyball. Data analysis used SPSS version 20. The results showed that there was a relationship between motor ability and basic volleyball technical skills in students. The conclusion from this study shows that in order to master the basic skills of playing volleyball optimally, a correlation of motor ability is needed 


\footnotetext{
Alamat korespondensi:

E-mail: Adirahadian@unsur.ac.id
}

e-ISSN : 2721-7175 (online)

p-ISSN : 2089-2341 (cetak)

\section{PENDAHULUAN}

Pendidikan jasmani dewasa ini, merupakan proses pendidikan yang sangat penting bagi perkembangan siswa. Pendidikan jasmani pada saat ini berdasarkan teori para ahli maupun literature yang ada, mampu meningkatkan kemampuan siswa dalam segi kognitif yang berkaitan dengan pengetahuan siswa, afektif yang berkaitan dengan sikap siswa, dan paling dominan yaitu perkembangan psikomotor atau berkaitan dengan kemampuan gerak siswa. Pendidikan jasmani memang memiliki manfaat yang sangat banyak, khususnya dalam mengembangkan kemampuan gerak. Kemampuan gerak atau motor ability telah diartikan sebagai kemampuan bawaan yang didapat dalam melakukan keterampilan motorik dari sifat umum dan mendasar. Secara tradisional, hal itu dipandang sebagai kombinasi faktor yang mendasar bagi semua gerakan yang melibatkan elemen kebugaran fisik seperti kekuatan, kecepatan, kelincahan, fleksibilitas (Sidhu, 2017). Para peneliti mendefinisikan motor ability sebagai efisiensi fisik umum, tingkat dimana seseorang telah mengembangkan kapasitas bawaannya untuk mempelajari lebih banyak keterampilan (Kumar, 2016).
Motor ability pada dasarnya merupakan faktor pembatas penampilan gerak seseorang, artinya baik atau buruknya keterampilan gerak yang ditampilkan tergantung dari motor ability yang dimiliki oleh orang tersebut. Secara signifikan, setiap orang berbeda dalam kemampuan gerak yang mereka miliki. Untuk itu, motor ability dijadikan sebagai kapasitas menunjukkan batas yang mempengaruhi pencapaian potensi seseorang dalam mempelajari sebuah keterampilan. Ada dua faktor yang menyebabkan perbedaan motor ability yang dimiliki oleh setiap orang, yang pertama yaitu faktor genetis dan yang kedua yaitu faktor non-genetik, seperti pengalaman latihan. Hasil penelitian Jekauc, et al (2017) menunjukan bahwa "Motor ability adalah sumber untuk membangun konsep diri dalam aktivitas fisik. Apabila motor ability berkembang dengan baik akan menghasilkan kinerja yang baik dalam olahraga dan latihan." Penelitian sebelumnya menemukan bahwa motor ability pada anak-anak laki-laki lebih unggul dalam tes koordinasi, kekuatan, kecepatan, sedangkan anak perempuan secara signifikan lebih baik dalam fleksibilitas dan keseimbangan (Prskalo \& Hraski, 2014). 
32 | Ahmad Suherly Dina Saputra1, Budiarto2, Muda Bhakti Hartanto3

Korelasi Antara Motor Ability Dengan Keterampilan Dasar Bermain Bola Voli

Pada Siswa Berusia 18-19

Banyak aktifitas jasmani yang berkaitan erat dengan motor ability, salah satunya adalah permainan bola voli. Permainan bola voli merupakan salah satu cabang olahraga permainan yang banyak digemari oleh siswa khususnya dan masyarakat pada umumnya. Perkebangan prestasi bola voli di Indonesia sangat diharapkan, sehingga menjadi kebanggaan bagi bangsa dan Negara. Langkah-langkah yang perlu dilakukan untuk mencapai hal tersebut diantaranya yaitu siswa harus mampu menguasai semua keterampilan dasar dalam bermain bola voli. Menurut Ahmadi (2007, hlm. 20) menjelaskan bahwa “Teknik-teknik dalam permaian bola voli terdiri atas servis, passing bawah, passing atas, block dan smash". Untuk belajar keterampilan dasar permainan bola voli, maka harus didukung faktor kemampuan gerak siswa (student motor ablity), karena dengan kemampuan gerak yang baik akan memudahkan siswa tersebut dalam mempelajari teknik dasar bermain bola voli. Seperti yang dijelaskan oleh Natraj, H. V. \& Kumar, C. (2006) bahwa "Keberhasilan dalam mempelajari komponen keterampilan tergantung oleh motor ability, yang saling berkaitan. Berdasarkan penjelasan di atas, dapat diartikan bahwa motor ability adalah kemampuan dalam hal keterampilan dasar untuk melakukan aktivitas gerak yang diperlukan dalam kegiatan olahraga. Artinya bahwa siswa yang memiliki tingkat motor ability yang rendah, akan mendapat kesulitan untuk mempelajarinya suatu keterampilan dan membutuhkan waktu yang lebih lama untuk pencapaian hasil belajarnya. Kemudian Henry (1961) dalam Hand, McIntyr \& Parker, (2018). membandingkan dua motor ability khusus antara, waktu reaksi dan kecepatan bergerak dan menemukan tdak ada korelasi diantara dua komponen tersebut. Studi lain membandingkan tugas keseimbangan dan kekuatan (hasilnya berkorelasi rendah.

Berdasarkan beberapa hasil penelitian terdahulu, dapat disimpulkan bahwa faktor motor ability, masih menjadi sebuah peredabatan diantara para peneliti, hal itu dikarenakan hasil yang diperoleh masih tidak konsisiten. Untuk memperjelas motor ability apakah berkorelasi dengan suatu keterampilan dasar bola voli, maka harus di uji lebih dalam melalui sebuah penelitian.

Apabila melihat permasalahan yang dihadapi oleh peneliti, pada siswa-siswa yang mengikuti kegiatan ekstrakurikuler di SMAN 1 Pacet, permasalahan yang paling utama adalah sulitnya siswa dalam menguasai keterampilan dasar yang ada dalam permainan bola voli, sehingga peneliti berasumsi bahwa hal itu ada kaitannya dengan motor ability siswa. Karena berdasarkan hasil penelitian Sudhakara (2018, hlm. 552) menemukan bahwa "There was a significant relationship found between the selected motor ability components on volleying ability of volley ball men players." Artinya 
33 Ahmad Suherly Dina Saputra1, Budiarto2, Muda Bhakti Hartanto3

Korelasi Antara Motor Ability Dengan Keterampilan Dasar Bermain Bola Voli

Pada Siswa Berusia 18-19

terdapat hubungan antara komponen motor ability dengan kemampuan dasar bermain bola voli.

Berdasarkan penjelasan di atas, maka tujuan utama dalam penelitian ini adalah menguji secara akurat korelasi antara motor ability dengan keterampilan bermain bola voli.

Metode

Dalam penelitian ini, peneliti menggunakan metode penelitian deskriptif. Seperti yang dikemukakan oleh Arikunto (2010, hlm. 3) metode penelitian deskriptif adalah "Penelitian yang dimaksudkan untuk menyelidiki keadaan, kondisi atau hal lain-lain yang sudah disebutkan, yang hasilnya dipaparkan dalam bentuk laporan. Populasi dalam penelitian ini adalah semua peserta didik yang mengikuti kegiatan ekstrakurikkuler bola voli yang berjumlah 30 orang di SMAN 1 Pacet. Pengambilan sampel dari populasi menggunakan teknik total sampling. Berdasarkan teknik total sampling di atas, maka sampel dalam penelitian ini adalah semua siswa yang mengikuti kegiatan ekstrakurikuler bola voli di SMAN 1 Pacet yang berjumlah 30 orang. Instrumen motor ability, secara teoritis bertujuan untuk mengukur kemampuan umum dari seseorang yang mencakup berbagai komponen kemampuan gerak (motor ability). Instrumen itu bernama barrow motor ability. Menurut Barrow (2013) dalam Nurhasan, dkk (2017) instrumen ini dapat memprediksi kemampuan motorik umum untuk laki-laki dalam jenjang SMA hingga tingkat perguruan tinggi. Tes ini terdiri dari beberapa butir tes yang disajikan pada Tabel 1.

Tabel 1. Butir Barrow Motor Ability Test

\begin{tabular}{|c|c|c|c|c|}
\hline Item & Factor & $\begin{array}{l}\text { Vali } \\
\text { dity }\end{array}$ & $\begin{array}{l}\text { Relia } \\
\text { bility }\end{array}$ & $\begin{array}{l}\text { Obje } \\
\text { ctivit } \\
y\end{array}$ \\
\hline $\begin{array}{l}\text { Standing } \\
\text { broad jump }\end{array}$ & Power & 759 & 895 & 996 \\
\hline $\begin{array}{l}\text { Softball } \\
\text { throw }\end{array}$ & $\begin{array}{l}\text { Arm- } \\
\text { shoulder } \\
\text { co-ord }\end{array}$ & 761 & 928 & 997 \\
\hline Zig-zag run & Agility & 736 & 795 & 996 \\
\hline Wall pass & $\begin{array}{l}\text { Hand-eye } \\
\text { co-ord }\end{array}$ & 761 & 791 & 950 \\
\hline $\begin{array}{l}\text { Medicine } \\
\text { ball put }\end{array}$ & Strength & 736 & 893 & 997 \\
\hline $\begin{array}{l}\text { 60-yard } \\
\text { dash }\end{array}$ & Speed & 723 & 828 & 997 \\
\hline
\end{tabular}

Instrumen kedua untuk mengukur tingkat keterampilan seorang siswa dalam melakukan teknik dasar bola voli mengacu kepada Nurhasan, dkk (2017, hlm. 213216). Butir item tes antara lain: (1) Passing, (2) Smash. Analisis data hasi tes dan pengukuran menggunakan SPSS versi 20.

Hasil

Hasil Deskriptif Data

Tabel 2 Deskriptif Data

\begin{tabular}{lrlll}
\hline Variabe & N Mi & M & M & Std \\
1 & ni & axi & e &. \\
& mu & mu & a & De \\
& m & m & n & viat \\
& & & & ion \\
\hline
\end{tabular}


$34 \mid$ Ahmad Suherly Dina Saputra1, Budiarto2, Muda Bhakti Hartanto3 Korelasi Antara Motor Ability Dengan Keterampilan Dasar Bermain Bola Voli Pada Siswa Berusia 18-19

\begin{tabular}{llllll}
\hline Motor & 3 & & & 2 & \\
Ability & 0 & & & 3. & 3.0 \\
& & 17 & 28 & \\
& & & & 0 & 11 \\
& & & 3 & \\
\hline Ketera & 3 & & 5 & \\
mpilan & 0 & & & 3. & 14. \\
Bermai & & 30 & 75 & 4 & 720 \\
n Bola & & & & \\
Voli & & & 7 & \\
\hline Valid N & 3 & & & & \\
(listwis & 0 & & & \\
e) & & & & \\
\end{tabular}

Berdasarkan Tabel 2 di atas, diperoleh nilai rata-rata variabel motor ability sebesar 23.03 dan nilai simpangan baku sebesar 3.011. Sedangkan nilai ratarata variabel keterampilan bermain bola voli sebesar 53.47 dan nilai simpangan baku sebesar 14.720 .

Hasil Pengujian Normalitas

Tabel 3. Hasil Penghitungan Normalitas Data

\begin{tabular}{llll}
\hline Variabel & Sig & $\alpha$ & $\begin{array}{l}\text { Keteranga } \\
\mathrm{n}\end{array}$ \\
\hline Motor & 0.43 & 0.0 & Data \\
Ability & 2 & 5 & Normal \\
\hline $\begin{array}{l}\text { Keterampil } \\
\text { an Bermain }\end{array}$ & 0.49 & 0.0 & Data \\
Bola Voli & 0 & 5 & Normal
\end{tabular}

Dari hasil penghitungan uji normalitas di atas, diperoleh nilai sig variabel motor ability sebesar 0.432 dan nilai sig keterampilan bermain bola voli sebesar 0.490. Maka dapat diartikan bahwa semua data berdistribusi normal karena nilai sig > $\alpha$ 0.05. Karena data berdistribusi normal, maka tahap selanjutnya adalah pengujian homogenitas data.

Hasil Pengujian Homogenitas Sampel

Tabel 4. Hasil Penghitungan Homogenitas Data

\begin{tabular}{llll}
\hline Variabel & Sig & $\alpha$ & $\begin{array}{l}\text { Keteranga } \\
\mathrm{n}\end{array}$ \\
\hline Motor & & & \\
Ability & 0.14 & 0.0 & Data \\
Keterampil & 2 & 5 & Homogen \\
an Bermain & & & \\
Bola Voli & & &
\end{tabular}

Dari hasil penghitungan uji homogenitas di atas, diperoleh nilai sig variabel motor ability sebesar 0.043 dan nilai sig keterampilan bermain bola voli sebesar 0.607. Maka dapat diartikan bahwa semua data bervariansi homogen karena nilai sig $>\alpha 0.05$. Karena data berdistribusi normal, maka tahap selanjutnya adalah pengujian homogenitas data.

Hasil Pengujian Hipotesis

Pengujian hipotesis berfungsi untuk menguji seberapa besar hubungan antara variabel motor ability dengan keterampilan bermain bola voli. Adapun hasil nilai penghitungannya disajikan pada Tabel 5 .

Tabel 5. Hasil Perhitungan Hipotesis

Dari hasil penghitungan uji korelasi di atas, diperoleh nilai korelasi antara motor ability dengan keterampilan bermain bola voli sebesar 0.504. Maka dapat diartikan bahwa terdapat hubungan antara motor ability dengan keterampilan teknik dasar bola voli pada siswa kelas ekstrakurikuler bola voli di SMKN 1 Pacet.

Simpulan 
35 Ahmad Suherly Dina Saputra1, Budiarto2, Muda Bhakti Hartanto3

Korelasi Antara Motor Ability Dengan Keterampilan Dasar Bermain Bola Voli

Pada Siswa Berusia 18-19

Motor ability merupakan

kemampuan dalam hal keterampilan dasar untuk melakukan aktivitas gerak yang diperlukan dalam kegiatan olahraga khususnya dalam mempelajari keterampilan dasar dalam bermain bola voli.

\section{DAFTAS PUSTAKA}

Ahmadi, Nuril. (2007). Panduan Olahraga

Bola Voli. Surakarta : Era Pustaka

Utama.

Arikunto, S. (2010). Prosedur penelitian :

Suatu Pendekatan Praktik. (Edisi

Revisi). Jakarta : Rineka Cipta.

Hands B, Fleur McIntyre, and Helen Parker (2018). The General Motor Ability Hypothesis: An Old Idea Revisited.

sagepub.com/journalsPermissions navDOI:

10.1177/0031512517751750.

Jekauc D, Matthias Oliver Wagner, Christian Herrmann, Khaled Hegazy, Alexander Wol. (2017). Does Physical Self-Concept Mediate the Relationship between Motor Abilities and Physical Activity in Adolescents and Young Adults?. PLoS ONE 2017; DOI:10.1371/journal.pone.01685 39.

Kumar M M, Vishan Singh Rathore. (2016). Speed and agility as predictors of long jump performance of male athletes.Turkish Journal of Sport and

Exercise.

http://dergipark.ulakbim.gov.tr/tse d/index.

DOI:

10.15314/tjse.40102.

Muhamad Syamsul Taufik (2019) Hubungan Tingkat Konsentrasi Dengan Keterampilan Bermain Futsal Unit Kegiatan Mahasiswa Futsal Universitas Suryakancana Gladi: Jurnal Ilmu Keolahragaan Jilid 10 Terbitan 02 Halaman 6878

Muhamad Syamsul Taufik (2014) Hubungan Antara Indeks Massa Tubuh, Fleksibilitas Dan Kecepatan Reaksi Dengan Kelincahan Pada Cabang

Olahraga Futsal Lembaga Universitas Pendidikan Indonesia Nurhasan, cholil Hasanudin. (2007). Modul Tes dan Pengukuran Keolahragaan. Bandung : FPOK.

Natraj HV, Kumar C. Selected motor ability variables and kabaddi performance. Journal of Sports and Sports Sciences. 2006; 29(1):6-11.

Nurhasan dkk. (2017). Panduan Melaksanakan Tes, Pengukuran Dan Evaluasi Dalam Pendidikan Jasmani dan Olahraga. Cianjur: PENDOR Universitas

Suryakancana. 
36 Ahmad Suherly Dina Saputra1, Budiarto2, Muda Bhakti Hartanto3

Korelasi Antara Motor Ability Dengan Keterampilan Dasar Bermain Bola Voli

Pada Siswa Berusia 18-19

Prskalo I \& Marijana Hraski. (2014). The relationship between motor abilities, physical activity and gender in preschool children. Merit Research Journal of Education and Review (ISSN: 2350 Available online http://www.meritresearchjournals. org/er/index.htm.

Sidhu J S. (2017). Anthropometric parameters and motor abilities among school children's.
International Journal of

Physiology, Nutrition and Physical Education 2018; 3(1): 366-369. ISSN: 2456-0057.

Sudhakara G. (2018). Examination of Motor Fitness in Skill Performance in Volleyball Men Players. International Journal of Physiology, Nutrition and Physical Education 2018; 3(1): 551-553. 